\title{
Conflict Resolution Strategies and Workplace Frustration and Organizational Citizenship Behavior: The Moderating Role of Emotional Intelligence
}

\author{
Aimen Mairaj \\ Research Scholar \\ Karachi University Business School, University of Karachi, Pakistan \\ E-mail: aimenmairaj@hotmail.com \\ Dr. Danish Ahmed Siddiqui \\ Associate Professor \\ Karachi University Business School, University of Karachi, Pakistan \\ E-mail: daanish79@hotmail.com \\ Accepted: July 26, 2020 \\ Published: August 19, 2020 \\ URL: https://doi.org/10.5296/hrr.v4i1.16568
}

Received: February 28, 2020

doi: 10.5296/hrr.v4i1.16568

\begin{abstract}
The purpose of this research is to determine the relationship between conflict resolution strategies (accommodating, avoiding, compromising, collaborating, and competing) with workplace frustration and organizational citizenship behavior (OCB) with the moderating role of trait emotional intelligence (EI) on their relations. Data was collected through a close-ended questionnaire from 298 employees (male $=197$, female $=101$ ) working at different private organizations of the manufacturing and service industry within the city of Karachi. The data were analyzed using confirmatory factor analysis and structured equation modeling. The results indicated that accommodating and avoiding strategies don't seem to have any effect on both frustration and OCB. Accommodating seems positively and significantly affect both. Compromising significantly and positively affect OCB, however, dominating is affecting frustration. Emotional Intelligence also seems to influences both OCB and frustration. EI also complements accommodating and collaboration strategies with
\end{abstract}


workplace frustration. This study is first of its kind in the local context in private sectors and paves the way for further research in the public sector.

Keywords: Conflict resolution, Conflict resolution strategies, Organizational citizenship behavior, Workplace frustration, Emotional intelligence

\section{Introduction}

\subsection{Background}

Conflict is an inevitable concept, daily we go through differing conflict situations. Organizational conflict may befall parties because of contradictory emotions about a certain issue, limited resources, incompatible ideologies, different values, lack of communication, and workplace practices, etc. These conflicts are likely to arise between individuals or groups because of differences in values, expectations, needs, workplace practices, and personalities, which, in turn, could produce conflicting actions and preferences. Rahim (2002) States conflict as "an interactive process manifested in incompatibility, disagreements, or dissonance within or between social entities (i.e. individual, group, organization, etc.)". Conflict is classically separated into two proportions: one contains disagreements of having issues relating to tasks and the other concern with emotional or interpersonal issues. Conflict management style holds immense significance as these circumstances affect our daily work life. Conflict management strategies are overripe most certainly by which how people see conflict and try to manage it. These handling methods force the individual to face and clash with them to alter as these methods are inclined by the concept of a character's importance of the person's vision and how they handle and control their association with others. The essentiality of any conflict is understandable especially among people like employees, managers, doctors, scientists, actors, etc. who work together daily in their professional lives. Employees at workplaces have daily exchange with a diversity of human beings together with peers, subordinates, supervisors, and managers. So, it is imperative to discover how their conflicts of everyday life are managed and handled properly. Conflict can be demarcated as an individual's effort over principles and for the accomplishment of safe status, influence, and resources, in tapering down the goals of challengers (Doherty \& Guyler, 2008).

Conflict stands up in the circumstances that are categorized by thoughts, opposing targets to achieve, or sentiments and they function inside or outside of a person and entities and this marshal to unfriendly or antagonistic collaboration. This sort of dealings among the person and his family, his working colleagues and his close surroundings of the people those varied in their personal goals and morals and personal tactics in line with their desirable goal line is called conflict. A conflict can also optimistic or adverse. Optimistic conflict is purposeful and cares or welfares the establishments or individual's chief objective (Oucho, 2002).

Studies on resolution strategies of conflicts and workplace frustration have been previously carried in an independent manner (Alper, Law, \& Tjosvold, 2000; Foran 2001; and Meyer 2004). Most of those studies link conflict resolution with work performance or work indicators (Alper et al., 2000; Meyer, 2004). But workers' feelings which are followed by a resolution process of conflict is not been studied appropriately. These feelings i.e. frustration within employees may relate can relate to the strategies for conflict resolution. Especially, a 
requirement is there to identify the aftermath of conflict resolution strategies (CRS) and its level on the feeling of working place frustration within the employees. It is right because a worker which is frustrated usually involves in behaviors such as, assassination of character of others, negative rumor spreading, behaving silent and cold towards other people, property of the company being prefaced, wasting available resources of the workplace and sabotaging (Foran, 2001; Perry, 2000), which impact negatively on individuals and the organization (Johnson \& Indvik, 2001; Pearson, Andersson, \& Porath, 2000).

Similarly, organizational citizenship behavior (OCB) is also linked with conflict resolution strategies. Organizational Citizenship Behaviors (OCB) are the behavior of the employee that is voluntary in and these behaviors not only aid in the success of the company but are important and necessary (McShane \& Von Glinow, 2000; Organ, 1988). There is a possibility that the employees of most of the firms or organizations use combination conflict resolution strategies to resolve conflicts arising at workplaces between their peers, managers or supervisors and them. But as such no previous studies have been carried out to know the link between the organizational citizenship behavior (OCB) and the conflict resolution strategies (CSR). This study shows what kind of conflict strategy will be adopted by the employees who possess the discretionary behavior of organizational citizenship. Many researchers have identified that organizational citizenship behavior (OCB) leads to the effectiveness of the organization, group performance efficiency (Podsakoff, Ahearne, \& MacKenzie, 1997) and unit performance (Podsakoff \& MacKenzie, 1994).

Abrahim (1999) and Carmeli (2003) were of the view that traits EI may enhance helping behavior and other citizenship behaviors because it enables employees to comprehend their superiors' and co-workers' feelings and to respond better than employees with low trait EI. Mikolajczak, Petrides, Luminet and Coumans (2007) found that high trait EI people display less of an increase in distress than their low trait EI peers in response to various adverse events or conditions in the workplace.

Conflict management researchers have suggested that conflict interpretation is the critical process preceding people's efforts to deal with conflict, as how people perceive a conflict is vital to how they react to that conflict (Gelfand et al., 2001; Pinkley, 1990; Pruitt, 1981; Thomas, 1976, 1992; Tjosvold, 2006). Social psychologists have found that an individual's effect influences his or her perception and cognition (Graziano \& Eisenberg, 1997; Graziano et al., 1996; Trapnell \& Wiggins, 1990). Thus, by incorporating the social psychology and conflict management studies, we can scrutinize the intermediation outcome of conflict frame on the connation between conflict management and affects.

\subsection{Problem Statement}

Conflict is inescapable in almost every organization. The exponential increase of conflict at the workplace affects the emotions of the employees negatively, which in return affects their performance and behaviors towards work negatively. In several organization conflicts leads to corroboration, and bring unnecessary competition, accusations ploys and deceptions, and unnecessary arguments. Conflicts also generate hostility among employees. These entire things combine produces negative behaviors of employees which eventually put them away from their targets and achieving their goal but this can be treated better if the supervisors or managers know the frustration level of the employee and their behavior towards their 
organizations. Conflict can take an overwhelming conclusion on the recital of an organization, particularly if it devours the dynamisms of staff instead of concentrating on creating events. (Ongari, 2009).

In simple words, we can conclude from above that it is the significant downfall of productivity, and that is occurring in Pakistan due to several possible reasons, cultural differences, and politics in the organization that managers fail to live up to when conflict arises. Nevertheless, spotting at the livelier side if correctly accomplished, conflict can "increase individuals', innovativeness and productivity" (Uline, Tschannenmoran, \& Perez, 2003) offer "interpersonal relationship satisfaction, creative problem solving, the growth of the global workforce, and domestic workplace diversity" (TingToomey \& Oetzel, 2001, p. 3).

Researchers must emphasis on proving solutions that can profit originations to resolve conflict problems relating to their employees like individuals and in teams, and having diverse culture or maybe diverse nationalities.

\subsection{Gap Analysis}

Several studies in an independent manner on conflict resolution and workplace frustration (Alper, Law, \& Tjosvold, 2000; Foran, 2001; Meyer, 2004). A Lot of studies have associated organizational conflicts with work indicators such as attitude and work performance (Alper, Law, \& Tjosvold, 2000; Meyer, 2004; Ogungbamila, 2006). However, the workers' feelings that process the process of conflict resolution have still been not studied accurately, such feelings of workplace frustration and organizational citizenship behavior (OCB). Previous studies carried out found a significant relationship between the Conflict resolution strategies and organizational citizenship behavior (OCB) and also the role of emotional intelligence on these relations as a moderator (Samuel, 2009). Previous studies also found a significant relationship between conflict resolution strategies and workplace frustration (Bolanle, 2006)

However, no research was carried out previously to study the relationship between these variables collectively. There are no studies about the simultaneous effect of emotional intelligence on the relationship between conflict resolution strategy and workplace frustration. Furthermore, these studies are conducted in western societies or countries actively but no such research related to this topic has been conducted in the workplace organizations of Pakistani society.

In Pakistani sociocultural setting feelings, emotions and sentiments are very vital attributes and cannot be ignored while talking about conflicts. Seeking out all these factors can benefit us go a long way in developing strategies that can solve these problems involving conflict and its core elements. In Pakistan, there is very little focus on proper conflict resolution, no proper or very little work has been done on this topic. This research paper assesses all five conflict resolution strategies and their relation with workplace frustration and organizational citizenship behavior and how these relations are affected by emotional intelligence to understand how to encounter and understand conflicts at the workplace better.

\subsection{Research Objectives}

As the growing conflict issues are increasing day by day, so it's become a necessity for an organization to reduce conflict at the workplace by having a proper conflict management strategy. This study is projected to explore that politics in organizations that give reasons to 
upsurge diverse conflicts that affect organizational obligations, job gratification, and business aims and eventually lessen the organizational productivity. Politics in organizational setup may perhaps disturb worker's behavior undesirably that causes conflicts between professionals. Furthermore, it can hinder the group procedure and generate strong relational resentment that team affiliates might not be eager to collaborate to attain administrative targets (Hackman \& Morris, 1975; Amason, 1996).

For this, research is conducted to analyze how we can identify conflicts and its repercussions among workers working in an organization. Our main focus is to understand and establish in what ways we can find conflict resolutions and conflict management strategies that occur in Pakistani organizational culture and general organizational culture. By understating employee level of workplace frustration and their behavior towards their organization (OCB) in Pakistani organizational culture and relate them to how they can solve the conflict. We also analyze if EI has a moderating effect on the relationship between workplace frustration and OCB. Emotional Intelligence can help employees manage their frustration and behavior within the organization.

We aim to fulfill the following objectives through this research;

To identify the relationship between conflict management strategies (accommodating, avoiding, collaborating, compromising and dominating) and workplace frustration?

To identify the relationship between conflict management strategies (accommodating, avoiding, collaborating, compromising and dominating) and organizational citizenship behavior (OCB)?

To identify the moderating role of moderator role of emotional intelligence (EI) on the relationship between conflict management strategies (accommodating, avoiding, collaborating, compromising and dominating) and workplace frustration?

To identify the moderating role of moderator role of emotional intelligence (EI) on the relationship between conflict management strategies (accommodating, avoiding, collaborating, compromising and dominating) and organizational citizenship behavior (OCB)?

\subsection{Research Question}

1) Do conflict resolution strategies have a relation with workplace frustration?

2) Do conflict resolution strategies have a relation with organizational citizenship behavior (OCB)?

3) Does emotional intelligence (EI) have an impact on these relations?

\subsection{Significance}

The importance of our study lies in the fact that it helped to collect feedback from people that aided to analyze the degree to which people are satisfied or not with the relationship conflict that occurs in day to day life in an organization so that the required changes and improvement could be made to ensure their conflict can be solved. Results of the study could also serve as an analytical tool for an organization to use to solve ongoing conflicts at the workplace and create a peaceful and wonderful working place where all manner of people can work and give their $100 \%$ to an organization so that organization can flourish remarkably, by assessing the 
relationships between the variables we have worked on in this research and their effects on each other. The research is significant because it will enlighten which conflict management strategy, people used when they have conflict. It will be helpful for people to choose a more efficient conflict management strategy that assists people to solve their conflicts effortlessly at their workplace and so that they can perform their jobs more efficiently. This learning will lead students, fellow philosophers and researchers to a new means of sketching vital refrains and its associations in the arena of conflict management that will aid researchers and experts to understand better modern-day strategies concerning conflict and its issues only.

\subsection{Scope}

This study is conducted within the territory of Karachi because of short period of time and limited resources and the questionnaire is filled by the manufacturing and service industry employees only.

\section{Literature Review}

Samuel (2009) investigated the relation of the conflict resolution strategies with the organizational citizenship behavior (OCB) and then the role of emotional intelligence as a moderator. The study was carried out on a sample of 320 employees out of which 180 male and 140 females and they all were public servants. The results found indicated that compromising strategies of conflict resolution predicted significantly OCB were accommodating, compromising and collaborating strategies. Whereas, avoiding and dominating strategies are negatively significant to OCB. Moreover, according to the research, Emotional intelligence as a moderator could only moderate the relation between the dominating and avoiding strategies with OCB.

Bolanle Ogungbamila (2006) assessed which conflict resolution strategies out of all the five are used by the managers or supervisors to resolve conflicts at the workplace and reduces the level of workplace frustration in their employees. To assess it 200 participants participated in it out of which 20 males and 20 females for each conflict resolution strategy. The results of the research interpreted that the dominating strategy had a direct strong relationship with workplace frustration. Whereas, the collaborating strategy is significant for reducing the level of frustration at the workplace. It was also concluded from the research that sharing information can be a source of frustration in the workplace among workers.

Canaan et al. (2016) explore the moderating effect of generations X and $\mathrm{Y}$ on the relationship between personality and conflict handling styles. The study is conducted using a sample of 199 employees working in the electronics retail sector in a non-Western culture. The five-factor model of personality traits is used to measure personality, while conflict styles are measured using Rahim's Organizational Conflict Inventory-II. Results indicate that generations $\mathrm{X}$ and $\mathrm{Y}$ moderate the relationship between specific personality traits and conflict handling styles.

Wenli (2010) observes how American and Chinese employees of multinational organizations deal with conflicts within organizations. In-depth interviews were conducted of 42 employees belonging to 28 different multinational organizations operating in China. The collected was analyzed and it was discovered that both American and Chinese employees used various strategies to deal with conflict, such as integrating, compromising, avoiding, and competitive 
and a third-party approach. It was also discovered that American participants are more likely to confront a conflict than Chinese participants. The results of this study also indicate that differing motivations lead to the utilization of a common conflict management strategy.

Judith (2013) proposed research-based principles of conflict management that are grounded in practical experience. The paper design approach presents a review of literature on topics related to each of the four proposed conflict management principles as well as practical advice on implementing the principles. The Key principles identified were: 1. take action early in the conflict cycle; 2 . use ground rules to encourage productive discussion of disagreements; 3 . discuss substantive conflict issues openly with the entire group; and 4. discuss interpersonal conflict issues with the entire group only if doing so is concurrent with the purpose, time availability, and skill set of the group.

Hopkins and Yonker (2015) examined the crucial correlation of (EI) abilities and (CMS) present in the organizational setup. 126 students in total took part in five distinct upper-level undergraduates and graduate management classes at a large level at Midwestern University. $56 \%$ were male. The average age was 23.96 ( $\mathrm{S} 1 / 43.97)$ years old. On average, participants had $6.17\left(\mathrm{~S}^{1 / 43.40)}\right.$ years of work experience and $1.04(\mathrm{~S} 1 / 41.93)$ years of experience at the management level. Results showed that the capabilities of EI in logical reasoning, communal obligation, and having command on their impulses remained mostly very much direct with members' way of dealing with things in their working environment.

Mingkai, Oluremi (2012) focused on the influence of trust on group processes and conflicts. The purpose of it is to discover the combined role of emotions and insecurity relating to the conflict and belief of the workers. For the research, statistics were collected from 325 senior students from a well-renowned commerce college. Outcomes displayed that task, relationship, and process conflict were linked with different aspects of positive emotional arousal (enthusiasm, excitement) and self-conscious emotions (guilt and shame). Likewise, behavioral guilt was connected with trust while emotions intermediated the link between conflict and trust. The findings propose that people need to increase acceptance during conflicts so that it can arouse job tensions to produce eagerness and exhilaration. Distinct sentiments are vital for developing veracity based on conviction.

Zhang et. al. (2015) examined the correlation of emotional intelligence (EI), conflict management styles (CMSs) and innovation performance, and verify the facilitating effects of several types of CMSs. Research data were attained from 159 employees in the construction industry in China. Results show that EI is absolutely and meaningfully connected with assimilating, cooperating and dominating styles, together with an innovation performance in the construction industry. Besides, the integrating style has an important positive correlation with innovation performance. This research also approves the intermediating effect of integrating style on the relationship between EI and innovation performance.

\section{Theoretical Framework}

\subsection{Workplace Frustration}

Mullins (1996), defined frustration as "Ö is a negative which the reaction to blockages related to goals desired or a form of defensive behavior. Similarly, workplace frustration is a reaction that is negative by a worker due to a blockage or barrier towards their goals which results 


\section{Macrothink}

from their participation in activities at the workplace. Workplace frustration can be traced to several factors, based on the stressor-emotion model (Goh, Bruursema, Fox, \& Spector, 2003), e.g., co-worker (Fletcher, 2001), non-participation in decision-making (Bogg \& Cooper, 1994), procedural injustice (Fox, Specter, \& Miles, 2001), and more importantly, superior-subordinate interface or exchange (Wesolowski \& Moss holder, 1997). The employees face workplace frustration when they face injustice at their workplaces, discrimination, or favoritism within the organization. Now if this behavior of frustration leads to a negative effect (Berkowitz, 1987; Neuman \& Baron, 1997), the worker could engage in counterproductive work behaviors directed at other individuals, and or the organization (Martinko, Gundlach, \& Douglas, 2002; Miles, Borman, Spector, \& Fox, 2002; Penney \& Spector, 2002; and Douglas \& Robinson, 2000). The workplace frustration which is the output of the interpersonal conflicts within the organization between employees can result in the nonproductive work behavior of the employees, malice between employees and disagreements. These counterproductive behaviors of the employees affect the efficiency, the productivity of the employees than that of the organization as a whole.

\subsection{Organizational Citizenship Behavior (OCB)}

Organizational Citizenship Behaviors (OCB) are the voluntary actions of the employees which are not assigned to them, those behaviors which not only aid to the success of the organization but also necessary for the success of the organization (Organ, 1988; McShane \& Von Glinow, 2001). Organ (1988) gave five types of OCB: altruism which involves helping another co-worker while they are doing a task; courtesy which involves helping during change the organization is going through which can affect their work; conscientious which involves doing the duty more than the requirements; sportsmanship involves stopping yourself from complaining about trivial issues and matters; and civic virtue involves taking part in the organization governance. Podsakoff and Mackenzie (1994) did the modification with these types of OCB, he merged with the altruism and courtesy with each other and named the new formed as "helping". Based on Organ's (1988) five-dimension taxonomy, Williams and Anderson (1991) they developed a concept of two-dimensions of OCB: OCB-I (behaviors directed toward individuals compromising altruism and courtesy) and OCB-O (behaviors directed toward the organization: comprising the remaining three-dimension in Organ's (1988) conceptualization).

3.2.1 OCB-I are the behaviors of the employees which indirectly aid in benefitting the individual of the organization which will eventually lead to the benefit of the respective organization. For example, doing the work for those who are absent or helping them in completing their work.

3.2.2 $O C B-O$ refers to those behaviors of the employees which directly aid in the benefit of the organization in general. For example; following the set rules and practices of the organization, informing the manager or supervisor before or in advance when the employee is unable to come. Decktop, Mangel, and Cirka (1999) used an overall OCB measure in the research they conducted. But the most recent analysis which was cried out by Hoffman, Blair, Meriac \& Woehr, (2007) proposed that recent view of OCB is the best view as indicators of a general OCB factor, there is likely little to be gained through the use of separate dimensional measures as opposed to an overall composite measure. A conclusion similar to this was 
analyzed too by LePine, Erez, \& Johnson, 2002. When there are fair processes within the organizations than the employees go out of their ways to help others within the organization (Organ, 1988). The fair process means the levels to which the organizational decisions are made equitably and with employee input. It also means the level to which the employees are rewarded fairly and training is given to them according to their requirements, responsibility, and workload (Moorman, 1991). In the same way, when there are conflicts within the organizations and employees are treated fairly then it is also counted in procedural fairness. Procedural fairness occurs when the employees feel that there are policies and rules in place that ensure fair treatment (Moorman, 1991). When managers or superiors use unfair procedures employee's sense of trust is affected. This can, in turn, have negative consequences on organizational citizenship behavior (Miles, Borman, Spector \& Fox, 2002; Podsakoff et al., 2000).

\subsection{Conflict}

Conflict is a derivative of beliefs relating to society and includes at least two parties who joint mismatched ideas. It is certain and obvious because it is an expected part of human relationships and it is part of a professional's daily life.

Conflict is a collaborating course that marks in a series or initiation-response counter-response (Folger \& Poole, 1984, p. 44). They gave a comprehensive summary of four superintendent philosophies in conflict dealings: 1. Designs of behavior in conflicts incline to spread itself. 2. As absurd and messy as conflict dealings may seem, it has a universal course which could be tacit. 3. Conflict interaction is sustained by the moves and countermoves of participants; moves and countermoves are based on the power participants exert. 4. Conflict interaction affects the relationship between participants.

Folger and Poole gave the concept of power as an effective tool to use positively in a given capacity to act efficiently in a given situation. Therefore, the generous and capacity of autonomy that the collective membership, spearhead of the pack and facilitator is prepared and able to engage has an excessive role to play in which it arises and is controlled. This, in turn, touches the total climate of the group and the relationships among group members. Folger and Poole (1984).

\subsection{Conflict Resolution strategies}

One social issue is the conflict between two or more people, communities, families, parties, communities, which disagree with each other (Dzurgba, 2006). A disagreement between two or more people is called Interpersonal conflict. A conflict including two or more organizational groups is called organizational conflict. These groups include unions, workers or management. People may have different interests, views, ideologies, aspirations, issues, goals which make organizational conflict common (Deutsch, 1990). An organization's efforts can be overshadowed by conflict, which is a negative consequence of conflict. But if it handled perfectly, the benefit can be gained by conflict by making a more resilient, stronger relation of work, making output creative and producing solutions that are innovative (Omoluabi, 2001).

A relational approach to handle conflicts is conflict resolution. The process in which interpersonal skills used to get to the parties to achieve a point amicable and satisfactory 
agreement (Albert, 2005; Omoluabi, 2001). There are five conflict resolution strategies: collaborating, avoiding, dominating, accommodating, and compromising, which are used by parties going through conflicts during conflict resolution process and are identified relying on the level of the win/lose orientation of parties involved (Meyer, 2004; Ogungbamila, 2006).

McShane and Von Glinow (2001) identified the view of cooperativeness and assertiveness, win-loss dimension and win-win dimensions in describing all the five strategies of conflict resolution. For instance, a person who uses dominating or avoiding strategy will possess low cooperativeness and high assertiveness. Also, they possess a less win-win attitude than the win-loss attitude.

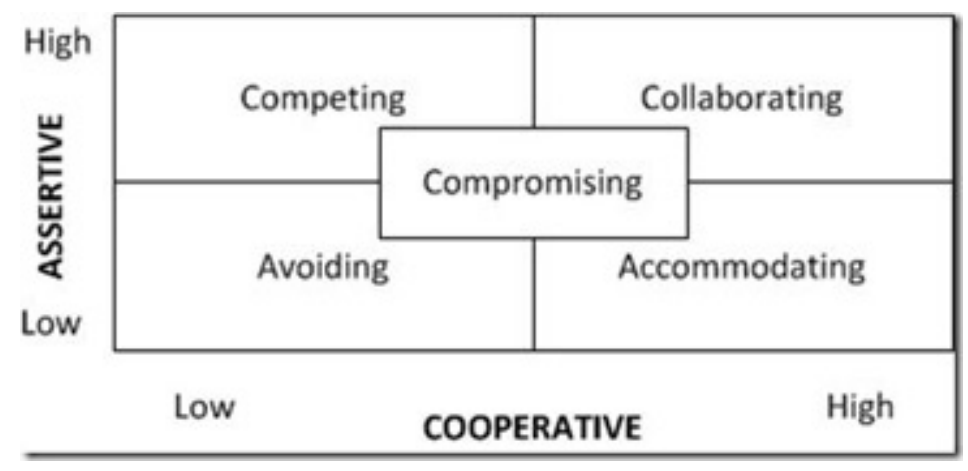

\subsubsection{Collaborating Strategy}

The Collaborative strategy of the conflict resolution possesses a party which is supposed to clarify the matter/issue with the other party involved. Cooperativeness and assertiveness are both found and an attitude of win-win on a high level. They may engender positive work behavior and attitudes of the parties in conflict (McShane \& Von Glinow, 2001). The clarifying party clarifies with the solution which is acceptable to all the other parties which are the part of the conflict. Problem-solving is another name given to this strategy and comes up with a neutral solution or idea which resolves the conflict. Through frankly and openly communicating it with all the parties (Flanagan \& Runde, 2008). Earlier studies have concluded that there is a positive significant relationship between people's jobs, their supervision, satisfying their tasks in general which collaborating strategy (Alexander, 1995). The benefit of this strategy style is that comes up with a decision that makes all the parties happy (Montoya-Weiss et al., 2001). But this strategy requires more effort than the other styles of conflict resolution as it has to make everyone stand on a single decision. This style is concerned with all the parties involved with satisfying the needs of both parties' desires. Therefore, both parties take an interest in correct information exchange which reaches to a mutual effective idea to the solution of the conflict which is acceptable to all and which leads to a win-win situation. The collaborating style of the conflict resolution works like putting an idea and then another idea and then another idea until it comes to the idea which is acceptable to all and the best solution to the conflict, high on cooperation and assertion. This solution which is the best solution would not have been achieved through a single person's idea but needed the efforts of all the brain involved. Therefore the output of such a solution is usually the most positive solution of all. An example can be if a team is deciding the parameters or setting the parameters to how they can work more effectively as a team then using the 
collaborating style will prove to be the most suitable style. it will allow the team to take the input of each team member and then come to a mutual solution.

$\mathrm{H}_{5}$ assumes that there is the possibility of having a significant relationship between the collaborating strategy of conflict resolution strategies with organizational citizenship behavior. As collaborating strategy deals with leading to a solution that is acceptable to all which will create a healthy peaceful workplace culture and will eventually leading to the behavior in which the employees own their organization. They will want to do more than the work assigned to them. Whereas, $\mathrm{H}_{6}$ assumes that there is a possibility of having a significant relationship between the collaborating strategy of conflict resolution strategies and workplace frustration as the collaborating style of resolution works on a mutual solution it can impact the workplace frustration found in employees.

The hypothesis relating to the collaborating strategy and are the part of this research are as follows;

$\mathrm{H}_{5}$ : There is a direct relationship between the collaborating strategy of CRS and organizational citizenship behavior (OCB).

$\mathrm{H}_{6}$ : There is a direct relationship between the collaborating strategy of CRS and Workplace frustration.

\subsubsection{Compromising Strategy}

Whereas the compromising strategy is more related to give and take the method to resolve the conflict between the parties, having high cooperativeness and low assertiveness. In this style of conflict resolution, all the parties involved will give something, negotiation will take place between the parties so that they can reach to a solution or an agreement (Yuan, 2007). This style will create an I-lose and I-win compromise scenario between the parties involved in the conflict. The people involved in the conflict will lead to changing their opinion because they find reasons to change it or to avoid themselves from continuing to confront more in this conflict (Lussier, 2010; Reich, Wagner-Westbrook, Kressel, 2007; Friedman, Tidd, Currall, $\&$ Tsai, 2005). The compromising strategy of resolution serves as an intermediate in both assertiveness and cooperativeness. This kind of resolution strategy is somehow a midway of accommodating and dominating strategies leading to a solution that is partially satisfying to both the parties involved.

$\mathrm{Th}_{7} \mathrm{H}_{7}$ assumes that there is a significant relationship between the compromising strategy of conflict resolution strategy and organizational citizenship behavior. As compromising strategy of resolution works like when both parties and come to a mid-point which is acceptable to all. Therefore it is assumed that it will create a peaceful environment where employees have a behavior of during more roles than roles assigned to them voluntarily because they feel like they own their organization and the same is the case with workplace frustration and compromising strategy. As the strategy is assumed to have a significant impact on the increasing or decreasing the level of employee frustration.

$\mathrm{H}_{7}$ : There is a direct relationship between the compromising strategy of CRS and organizational citizenship behavior (OCB).

H8: There is a direct relationship between the compromising strategy of CRS and workplace frustration. 


\section{$\Lambda$ Macrothink}

\subsubsection{Dominating Strategy}

The dominating strategy of conflict resolution involves a forcing strategy to force their point of view on others which makes it high on assertiveness and is associated with a win-loss attitude of the parties and can lead to negative behavior towards work. They are the people who use behavior that is aggressive while solving conflicts. This behavior includes threats, authorities, and styles which are intimate to force the opposite party to make them agree on their opinion (Lussier, 2010; Rahim \& Bonoma, 1979). In this style, people put their concerns over everyone's concerns and on other's expense. People who use this strategy od conflict resolution use their power over the other party, their ability, rank or economic sanctions to use their influence over the other party. The dominating strategy is also termed as the competing strategy, which means standing for your right or proving yourself right or making yourself win by dominating. The person achieves or pursues their goal's through the other expenses. This style of conflict resolution is also termed as the forcing or imposing style that is why because this strategy ensures that the opposing party loses through the other party using their power, aggression, and dominance over them.

Here $\mathrm{H}_{9}$ assumes, that there is a significant relationship between the dominating strategy of CRS with organizational citizenship behavior (OCB) of the employees. As the dominating strategy works like winning over others through using your power, rank and forcing your opinion over the other party. Therefore, it is assumed that it affects the behavior of the employees towards their organization. It may increase organizational citizenship behavior or decrease it within employees towards their workplace. Similarly, $\mathrm{H}_{10}$ assumes whether there is a relation between the dominating strategy and workplace frustration. Whether the employees who prefer to use this strategy while resolving a conflict have a high level of workplace frustration or low.

$\mathrm{H}_{9}$ : There is a direct relationship between the dominating strategy of CRS and organizational citizenship behavior (OCB).

$\mathrm{H}_{10}$ : There is a direct relationship between the dominating strategy of CRS and workplace frustration.

\subsubsection{Accommodating Strategy}

Whereas, the accommodating strategy has low assertiveness and a high level of cooperativeness and highlights the point which is acceptable to both parties. This strategy of resolving the conflicts is called both obliging and smoothing. In this style of resolving the conflicts, the person is more concerned about others than their very own self. The needs of the others come first then come to the needs of that individual. They sacrifice or give up on their needs to meet the other's needs. It is thus non-confrontational associated with playing down differences and focusing on relationships, cooperation, and harmony, and therefore putting aside one's needs to please the other party in a conflict situation. (Wilmot \& Hocker, 2001). In this style of resolving conflict the employees cooperate to a very high level/degree, they meet the other's concerns on their expenses and usually work against their very own objectives, goals, and desires. This strategy is mostly more effective when the opposite party is more experienced and they are most probably right or have the right solution to the problem. This strategy is also effective in employee relationships. This strategy 
accommodating strategy is the opposite of dominating strategy, it is high on cooperation and almost unassertive. While accommodating the person forgets his or her concerns while satisfying others' concerns. It has an element of selfless generosity, sacrifice, charity and obeying others' points of view rather than their view.

Here, the $\mathrm{H}_{1}$ assumes that there is a significant relation between accommodating strategy and organizational citizenship behavior (OCB). If a person prefers using the accommodating strategy then he/she will give up over their concerns and goals to meet other person's goals. They have an element of selflessness and sacrifice. It is assumed that their behavior may affect the behavior of organizational citizenship. In the case of $\mathrm{H}_{2}$, it is assumed that a similar strategy of resolving the conflict has an impact on the workplace frustration of the employees. It can be negative or positive.

$\mathrm{H}_{1}$ : There is a direct relation between accommodating strategy of CRS and organizational citizenship behavior (OCB)

$\mathrm{H}_{2}$ : There is a direct relationship between the accommodating strategy of CRS and workplace frustration.

\subsubsection{Avoiding Strategy}

Avoiding Strategy of the conflict resolution strategies is concerned with low concerns for both yourself and others. This case usually reaches to the withdrawal point because the employees who use this strategy nor meet their goals or let the other party meet their goals. The avoidance strategy involves the element of ignoring, suppressing and refusing to take the issue in an account. In this case, the issues are avoided because usually they are so minor so they are not addressed and you don't help the other party to make it to their goals as well as you don't achieve or pursuing yours. People usually use it when they know that they have no chance of winning but they don't let others win as well. Avoiding strategy is both uncooperative and unassertive as the issues are not being addressed or being solved through a proper solution or by just simply avoiding them. In short, the avoiding strategy does not last long. It is not a long-term strategy. The only time of using it and it is effective is when the issue is so expensive. Only then to save the resources, it is more effective to avoid the issue if it is not directly or indirectly causing any prominent harm to the organization or the employees.

$\mathrm{H}_{3}$ assumes that there may be a significant relationship between avoiding strategy and organizational citizenship behavior (OCB). As the avoiding strategy works like when the issue is not addressed or taken into account or simply being avoided. It is assumed that if this strategy of resolving the conflict is used or preferred by the employees then this may affect their organizational citizenship behavior negatively or positively. Similarly, the $\mathrm{H}_{4}$ assumes that this strategy may also have an impact on the workplace frustration level of the employees negatively or positively if they prefer to use this approach for solving conflicts.

$\mathrm{H}_{3}$ : There is a direct relationship between the avoiding strategy of CRS and organizational citizenship behavior (OCB).

$\mathrm{H}_{4}$ : There is a direct relationship between the avoiding strategy of CRS and workplace frustration. 


\subsection{Emotional Intelligence}

Emotional intelligence (EI) is a concept developed which accounts for the individual's ability to regulate their emotions. Emotional intelligence (EI) focuses on providing a framework that gives an idea that everyone differs the level to which they process and regulate their emotions (intrapersonal) others' emotions (interpersonal) natures (Petrides \& Furnham, 2003). In easier words, emotional intelligence represents the skills, capacity, ability and self-recognized ability to define, evaluate, understand and run the emotions of yourself and the people around you. The critics claim that emotional intelligence is insanely vague of a concept so it cannot be measured or hard to know it is valid or not (Robbins \& Judge, 2009). Researchers even also have a view about emotional intelligence that to have an exact definition for emotional intelligence is immensely difficult because most of the researchers consider different skills when they measure or define emotional intelligence. If a researcher is considering the element of empathy, the other may be considering self-control. Critics even say that is it even possible to measure emotional intelligence or not. The critics argued if the EI is a form of intelligence then test of EI were conducted then they argued if the answers are whether right or wrong from those test then they argued if the test conducted for EI are even valid or not and the finally came to the idea and contest the validity of emotional intelligence based on it being closely related to the personality and the intelligence (Robbins \& Judge, 2009). Emotional intelligence (EI) has two types; trait EI and ability trait (Furnham \& Petrides, 2003).

3.5.1 Trait EI can be operationalized through the measure of self-report like questionnaires (Furnham \& Petrides, 2003). It is a constellation of emotional related self-perceived abilities and dispositions located at the lower levels of personality hierarchies (Petrides \& Furnham, 2001). Trait EI is the ability of the individual to accurately perceive and express their emotions (Mayer \& Salovey, 1997). On the other side, ability EI is operationalized through a large number of performance-based tests that can be answered correctly or incorrectly (Mayer \& Salovey, 1997).

3.5.2 Ability EI is considerably complicated by the fact that emotional experiences are inherently subjective (Furnham \& Petrides, 2003) and are not amenable to objective scoring criteria. Ability EI is defined as the ability to perceive accurately, appraise, and express emotion; the ability to access and/or generate feelings when they facilitate thought; the ability to understand emotion and emotional knowledge; and the ability to regulate emotions to promote emotional and intellectual growth (Mayer \& Salovey, 1997). It is easier to administer self-report measures of trait EI with subjects and it takes less time to administer them. However, ability EI measures are based on maximum performance tests that require the researchers' responses. Laboratory experiments may require participants to complete lengthy and complicated tasks (Geher, Warner, \& Brown, 2001). There are some abilities of the emotional intelligence which are likely to influence the workplace behaviors. For example, the ability to regulate emotions has been a prerequisite to maintain relations at the workplace (Martin, Knopoff, \& Beckman, 1998). In line with these studies, we can assume that emotional intelligence can influence the employee's feelings, behavior, and conflict resolution styles as well. 


\section{Macrothink

In this research, the role of emotional intelligence (EI) is of a moderator. This research shows how EI will moderate or affect the relation of organizational citizenship behavior (OCB) with the respective conflict resolution strategies i.e. Accommodating, Collaborating, Dominating, Compromising and Avoiding. Similarly, it also shows how emotional intelligence (EI) will moderate or affect the relationship between workplace frustration with conflict resolution strategies i.e. Accommodating, Collaborating, Dominating, Compromising and Avoiding. Keeping in mind the following hypothesis related to emotional intelligence is taken for the research;

$\mathrm{H}_{11}$ : Emotional intelligence (EI) has an impact on the relation between accommodating strategy and workplace frustration.

$\mathrm{H}_{12}$ : Emotional intelligence (EI) has an impact on the relation between avoiding strategy and workplace frustration.

$\mathrm{H}_{13}$ : Emotional intelligence (EI) has an impact on the relation between collaborating strategy and workplace frustration.

$\mathrm{H}_{14}$ : Emotional intelligence (EI) has an impact on the relation between compromising strategy and workplace frustration.

$\mathrm{H}_{15}$ : Emotional intelligence (EI) has an impact on the relation between dominating strategy and workplace frustration.

$\mathrm{H}_{16}$ : Emotional intelligence (EI) has an impact on the relation between accommodating strategy and organizational citizenship behavior (OCB)

$\mathrm{H}_{17}$ : Emotional intelligence (EI) has an impact on the relation between avoiding strategy and organizational citizenship behavior (OCB).

$\mathrm{H}_{18}$ : Emotional intelligence (EI) has an impact on the relation between the collaborating strategy and organizational citizenship behavior (OCB)

$\mathrm{H}_{19}$ : Emotional intelligence (EI) has an impact on the relation between the compromising strategy and organizational citizenship behavior (OCB)

$\mathrm{H}_{20}$ : Emotional intelligence has an impact on the relation between the dominating strategy and organizational citizenship behavior (OCB).

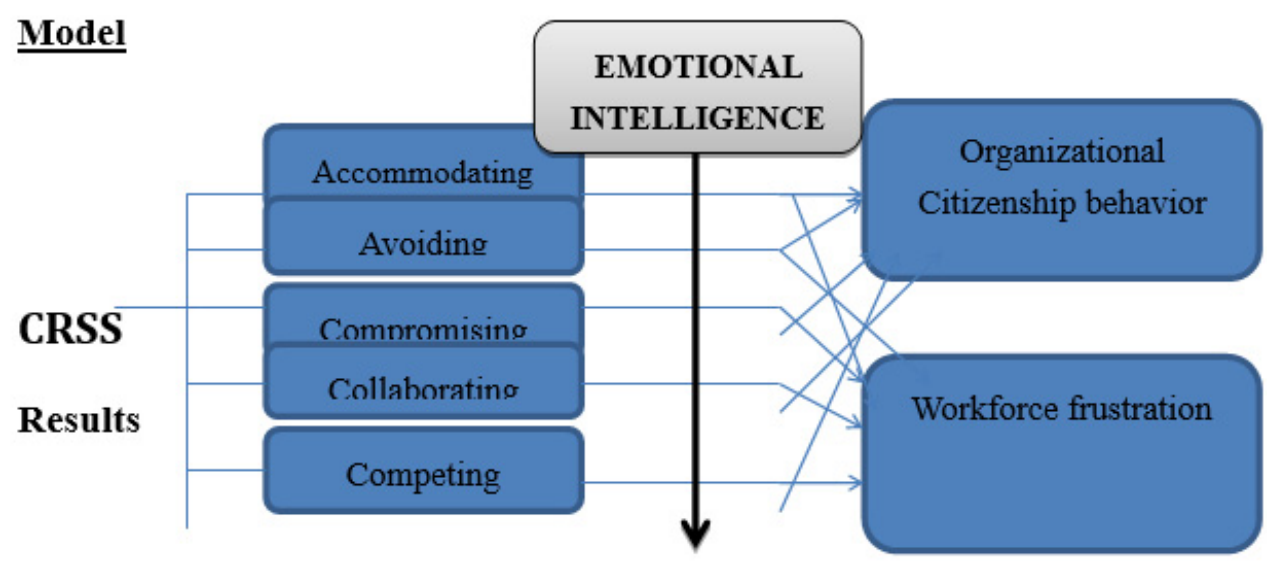




\section{Al Macrothink}

Human Resource Research

ISSN 1948-5441 2020, Vol. 4, No. 1

The independent variables were the conflict resolution strategies; accommodating, avoiding, collaborating, compromising and dominating. The dependent variables were workplace frustration and organizational citizenship behavior (OCB). Whereas, emotional intelligence (EI) is the moderator.

\section{Research Methodology}

\subsection{Participants}

Two Hundred and Ninety-Eight participants responded to the survey. One Hundred and Ninety-Seven were males and One Hundred and One female. Their ages of the respondents ranged from 20years-50years $\&$ above. The educational qualification of the participants was between intermediate to M.Phil./PhD. The working experience of the participants ranged between 1-10 years. The respondents were selected randomly working at the private organizations of the manufacturing and service industry.

4.2 Demographic Analysis

\begin{tabular}{llll}
\hline Variable & Category & Frequency & Percentage \\
\hline Gender & Male & 197 & 66.1 \\
& Female & 101 & 33.9 \\
Total & $\mathbf{2 9 8}$ & $\mathbf{1 0 0}$ \\
Age & 123 & 41.2 \\
& 20-24years & 79 & 26.5 \\
25-29years & 33 & 11.07 \\
30-34years & 22 & 7.3 \\
35-39years & 18 & 6.04 \\
40-44years & 15 & 5.03 \\
45-49years & 8 & 2.68 \\
Education & 50\& above & $\mathbf{2 9 8}$ & $\mathbf{1 0 0}$ \\
& Total & 11 & 3.69 \\
& Intermediate & 183 & 61.4 \\
& Graduate & 78 & 26.1 \\
& Post-graduate & 26 & 8.72 \\
M.Phil./Ph.D. & $\mathbf{2 9 8}$ & $\mathbf{1 0 0}$ \\
Total & 174 & 58.3 \\
1-3years & 87 & 29.1 \\
4-6years & 22 & 7.3 \\
7-9years & 15 & 5.03 \\
10years \& above & $\mathbf{2 9 8}$ & $\mathbf{1 0 0}$ \\
\hline
\end{tabular}




\section{Macrothink}

The demographic information of respondents included gender, age, education, and working experience. Results from frequency distribution suggest that $66.1 \%$ of male and $33.9 \%$ female respondents completed this questionnaire in the survey. The percentage of respondents lying in the bracket of 20-24years old (41.2\%), 25-29years old (26.5), $30-34$ years old $(11.07 \%)$, 35-39years old $(7.3 \%)$, 40-44 years old $(6.04 \%)$, 45-49 years old $(5.03 \%)$, whereas, $(2.68 \%)$ for 50 and above years old. This table shows that $(3.69 \%)$ respondents belonged to intermediate level of education, $(61.4 \%)$ have education till graduation level, $(26.1 \%)$ did post-graduation and (8.72\%) are M.Phil./Ph.D. In the frequency table, most of the respondents $(58.3 \%)$ had a working experience of $1-3 y e a r s, ~(29.1 \%)$ had a working experience of 4-6years, $(7.3 \%)$ respondents had an experience of 7-9 years, whereas, $(5.03 \%)$ had a working experience of 10years and above.

\subsection{Instruments}

Rahim Organizational Conflict Inventory (Rahim, 1983) was used to measure the behavior of the participants with their supervisors when resolving conflicts in the workplace on a 5-point scale $(1=$ strongly disagree to $5=$ agree). The Rahim Organizational Conflict Inventory (Rahim, 1983) is a 28-item inventory with 5 subscales consisting of accommodating, avoiding, compromising, collaborating, and competing respectively. 3-items of each subscale were adapted to analyze the behavior of each respondent toward each CRS strategy. Some sample items for each subscale of CRS are: I generally try to satisfy the needs of my supervisor (accommodating), I try to stay away from disagreement with my supervisor (avoiding), I exchange accurate information with my supervisor to solve a problem together (collaborating), I try to find a middle course to resolve an impasse (compromising), I use my influence to get my ideas accepted (dominating).

Job Satisfactory Survey (Paul. E. Spector, 1994) was used to measure the workplace frustration, which assessed the level of work-related satisfaction and frustration (from their co-workers, superior, the organization, and the job itself) experienced by the participants in their workplace, on a 6-point scale ( $1=$ disagree very much; $6=$ agree very much). This is an 18-item from which 8 were adapted to calculate the level of respondents' workplace frustration. Some sample items are: I feel I am being paid a fair amount for the work I do; I sometimes feel my job is meaningless.

Organizational Citizenship Behavior Scale (Podsakoff, 1990) was used to measure the OCB of the respondents. 7-items were adapted from Organizational Citizenship Behavior Scale (Podsakoff, 1990), on a 5-point scale ( $1=$ strongly disagree to $5=$ strongly agree). Some sample items: I willingly help fellow professionals when they have work-related problems; I obey organizational rules even when no one is watching.

Wong and Law Emotional Intelligence Scale (WLEIS), 2002 was used to measure the trait emotional intelligence (EI). 7-items were adapted from the scale to measure the emotional intelligence of the participants, on a 5-point scale ( $1=$ strongly disagree to $5=$ strongly agree). Some sample items: I have a good understanding of my own emotions; I have a good understanding of the emotions of people around me. 


\section{Macrothink}

Human Resource Research

ISSN 1948-5441 2020, Vol. 4, No. 1

4.4 Descriptive Statistic

\begin{tabular}{|c|c|c|c|c|c|c|}
\hline \multirow[t]{2}{*}{ Variables } & \multirow[t]{2}{*}{ Questions } & \multicolumn{2}{|c|}{$\begin{array}{l}\text { Descriptive } \\
\text { stats }\end{array}$} & \multicolumn{2}{|c|}{$\begin{array}{l}\text { Confirmatory } \\
\text { Analysis }\end{array}$} & \multirow{2}{*}{$\begin{array}{c}\text { Factor } \\
\text { P-values }\end{array}$} \\
\hline & & Mean & St.dev. & $\begin{array}{l}\text { Outer } \\
\text { loading }\end{array}$ & T-stats & \\
\hline \multirow[t]{3}{*}{$\begin{array}{l}\text { Conflict resolution } \\
\text { collaborating strategy }\end{array}$} & $\begin{array}{l}\text { I try to investigate an issue with my } \\
\text { supervisor to find a solution acceptable } \\
\text { to us. }\end{array}$ & 3.793 & 0.949 & 0.762 & 18.967 & 0.000 \\
\hline & $\begin{array}{l}\text { I exchange accurate information with } \\
\text { my supervisor to solve a problem } \\
\text { together. }\end{array}$ & 3.916 & 1.030 & 0.893 & 72.458 & 0.000 \\
\hline & $\begin{array}{l}\text { I collaborate with my supervisor to } \\
\text { come up with decisions acceptable to } \\
\text { us. }\end{array}$ & 4.00 & 0.850 & 0.832 & 33.674 & 0.000 \\
\hline \multirow[t]{3}{*}{$\begin{array}{l}\text { accommodating } \\
\text { strategy }\end{array}$} & $\begin{array}{l}\text { I generally try to satisfy the needs of my } \\
\text { supervisor. }\end{array}$ & 3.609 & 0.920 & 0.786 & 19.527 & 0.000 \\
\hline & $\begin{array}{l}\text { I usually allow concessions to my } \\
\text { supervisor. }\end{array}$ & 3.378 & 0.789 & 0.722 & 13.087 & 0.000 \\
\hline & $\begin{array}{l}\text { I try to satisfy the expectations of my } \\
\text { supervisor. }\end{array}$ & 3.786 & 0.858 & 0.847 & 28.194 & 0.000 \\
\hline \multirow[t]{3}{*}{ dominating strategy } & $\begin{array}{l}\text { I use my influence to get my ideas } \\
\text { accepted. }\end{array}$ & 2.963 & 1.186 & 0.806 & 2.430 & 0.015 \\
\hline & $\begin{array}{l}\text { I use my expertise to make a decision in } \\
\text { my favor. }\end{array}$ & 3.518 & 1.039 & 0.697 & 2.496 & 0.013 \\
\hline & $\begin{array}{l}\text { I sometimes use my power to win a } \\
\text { competitive situation. }\end{array}$ & 2.953 & 1.223 & 0.845 & 2.304 & 0.021 \\
\hline \multirow[t]{3}{*}{ compromising strategy } & $\begin{array}{l}\text { I try to find a middle course to resolve } \\
\text { an impasse. }\end{array}$ & 3.301 & 0.807 & 0.537 & 3.011 & 0.003 \\
\hline & $\begin{array}{l}\text { I negotiate with my supervisor so that a } \\
\text { compromise can be reached. }\end{array}$ & 3.622 & 0.827 & 0.918 & 11.115 & 0.000 \\
\hline & $\begin{array}{l}\text { I use "give and take" so that a } \\
\text { compromise can be made. }\end{array}$ & 3.344 & 0.970 & 0.682 & 5.396 & 0.000 \\
\hline \multirow[t]{2}{*}{ avoiding strategy } & $\begin{array}{l}\text { I attempt to avoid being "put on the } \\
\text { spot" and try to keep my conflict with } \\
\text { my supervisor to myself. }\end{array}$ & 3.134 & 1.125 & 0.920 & 1.084 & 0.278 \\
\hline & $\begin{array}{l}\text { I try to stay away from disagreement } \\
\text { with my supervisor. }\end{array}$ & 3.572 & 1.014 & 0.669 & 1.083 & 0.279 \\
\hline
\end{tabular}


I try to avoid unpleasant exchanges with $3.555 \quad 1.133 \quad 0.546$

$1.014 \quad \mathbf{0 . 3 1 1}$

my supervisor.

Workplace frustration When I do a good job, I receive the $4.097 \begin{array}{lll}1.337 & 0.790\end{array}$ recognition for it that I should receive.

I feel I am being paid a fair amount for the $3.318 \quad 1.432 \quad 0.800$

$31.152 \mathbf{0 . 0 0 0}$ work I do.

Communications seem good within this $3.676 \quad 1.368 \quad 0.744$

$21.006 \mathbf{0 . 0 0 0}$ organization

Many of our rules and procedures make $3.816 \quad 1.271$

$-0.207$

$2.411 \quad 0.016$ doing a good job difficult.

I find I have to work harder at my job $3.746 \quad 1.504$

$-0.506$

$6.165 \mathbf{0 . 0 0 0}$ because of the incompetence of people I

work with.

I like doing the things I do at work

Those who do well on the job stand a fair $4.528 \quad 1.457 \quad 0.404$

$6.317 \quad 0.000$ chance of being promoted.

I sometimes feel my job is meaningless $2.806 \quad 1.624$

$-0.642 \quad 12.963 \quad \mathbf{0 . 0 0 0}$

Organizational

I willingly help fellow professionals 3.9430 .940

0.809

$30.684 \mathbf{0 . 0 0 0}$

citizenship behavior when they have work related problems.

(OCB)

I attend meetings that aren't compulsory $3.358 \quad 1.161$

but help my department anyway.

I am always ready to lend a helping 3.9430 .896

0.783

$26.125 \mathbf{0 . 0 0 0}$

hand to those around me

I obey organizational rules even when $3.431 \quad 0.980 \quad 0.622$

$12.788 \mathbf{0 . 0 0 0}$ no one is watching

I usually focus on what is wrong rather 3.1671 .027

$-0.292$

$3.270 \quad \mathbf{0 . 0 0 1}$

than positive side of situation

$\begin{array}{llllllll}\text { I always require frequent doses of } 3.281 & 1.012 & -0.142 & 1.497 & \mathbf{0 . 1 3 5}\end{array}$ motivation to get the work done.

I am mindful of how my behavior $3.746 \quad 0.867 \quad 0.704$ affects other people's jobs.

$\begin{array}{llll}\text { I have a good understanding of my own } & 3.876 & 0.933 & 0.640\end{array}$ emotions.

I am quite capable of controlling my $3.716 \quad 0.934 \quad 0.727$ own emotions.

I have a good understanding of the $3.462 \quad 0.8390 .754$ emotions of people around me. 


\author{
I am able to control my temper so that I $3.559 \quad 0.964 \quad 0.762 \quad 29.759 \quad \mathbf{0 . 0 0 0}$ \\ can handle difficulties rationally. \\ I $\quad$ am a good observer of other's $3.599 \quad 0.939 \quad 0.733 \quad 17.761 \quad \mathbf{0 . 0 0 0}$ \\ emotions. \\ I always know my friend's emotions $\begin{array}{lllll}3.696 & 0.898 & 0.739 & 23.044 & \mathbf{0 . 0 0 0}\end{array}$ \\ from their behavior. \\ I am a self-motivating person. $\quad \begin{array}{lllll}3.732 & 1.016 & 0.735 & 22.537 & \mathbf{0 . 0 0 0}\end{array}$
}

\title{
4.5 Procedure
}

Participants were randomly selected. Questionnaires were distributed to them at their workplaces. Participants have been explained the purpose of the study which was given as academic research. Participants were explained that the questionnaire will collect the data regarding their rating of the conflict resolution strategies which is used by them in their organizations to resolve or overcome a conflict, their perceived organizational citizenship behavior (OCB), their level of workplace frustration and the trait emotional intelligence. A section of the questionnaire had background information on the participant's gender, age, education, and working experience. The questionnaires were completed anonymously by the participants in their offices, units or departments. Some of the questionnaires were filled online. Data were collected from 298 respondents.

\section{Structural Equation Modeling}

To test the study hypothesis we have used the structural equation model (SEM) whereas the testing has been gone through Smart PLS software. Moreover, to evaluate the indirect and direct effects of all the constructs the testing was done. The use of (SEM) structural equation model has been observed to be a foremost procedure that has been used below different regression models and methods (Barron \& Kenny, 1986). It used to evaluate the structural relationship between exogenous and endogenous variables. It includes factor analysis and multivariate analysis. Moreover, the equation of regression targets at explaining each construct to assess the cause and effect relationship while all of the factors in the causal model could demonstrate their cause and effect at the exact time. Likewise, the idea of using this model ensures to apply the technique of bootstrapping which has been viewed as reasonable for both small and large sample sizes and does not require any kind of indirect effect (Hayes, 2013). To check all direct and indirect effects, a technique has been implemented which is known as bootstrapping (Shrout \& Bolger, 2002).

\subsection{Measurement of Outer Model}

The goal of the measure of fit in the measurement model is to study the reliability and validity of the instrument and to check its reliability and validity we perform the test of convergent validity and discriminant validity in software naming Smart PLS.

Composite Reliability

Reliability implies the stability of questionnaire outcomes. For a similar target population, at whatever point the questioner reutilizes the questionnaire it will give a similar outcome. It demonstrates inside consistency \& repeatability of the survey are high. The primary measure 


\section{Macrothink Institute ${ }^{\text {TM }}$}

for unwavering quality is to maintain a strategic distance from unfairness in research. In this manner, it tends to be improved by testing the pursuit procedure and investigation, as is done utilizing diverse research and examination techniques or different researchers. This also incorporates the dependability and legitimacy of the exploration. The Reliability of the measurement instruments was evaluated using composite reliability. All the values were above the normally used threshold value i.e. 0.70 . This is the accepted reliability value range. Estimation of reliability can be done by the degree of constancy that lies amongst various variables (Hair, 2010). Below is the table of composite reliability.

\begin{tabular}{ll}
\hline Variables & Composite Reliability \\
\hline Accommodating strategy & 0.691 \\
Avoiding strategy & 0.635 \\
Collaborating strategy & 0.785 \\
Compromising strategy & 0.601 \\
Dominating strategy & 0.697 \\
Workplace frustration & 0.211 \\
Organizational citizenship behavior (OCB) & 0.657 \\
Emotional Intelligence (EI) & 0.849 \\
\hline
\end{tabular}

\subsection{Factor Loadings Significant}

A table of descriptive statistics also mentioned loadings used in (CFA) confirmatory factor analysis. Construct with the loading of .5 are consider as strong loading variables whereas the constructs with the loading of below .5 are considered as less is better to be removed from the table.

\subsection{Convergent Validity}

Convergent validity is the level of agreement in at least two measures of a similar construct (Carmines \& Zeller, 1979). Convergent validity was assessed by inspection of variance mined for each factor (Fornell \& Larcker, 1981). Conferring to Fornell and Larcker (1981), if the variance extracted value is greater than 0.5 then convergent validity is established and the result is drawn that the loadings are good but less than 0.5 are termed as less effective for the study. Following table displays the result.

\begin{tabular}{|c|c|c|c|c|}
\hline & Cronbach's Alpha & rho_A & Composite Reliability & Average Variance Extracted (AVE) \\
\hline CRS ACCOMODATING & 0.692 & 0.704 & 0.691 & 0.431 \\
\hline CRS AVOIDING & 0.644 & 0.932 & 0.635 & 0.443 \\
\hline CRS COLLABRATING_ & 0.778 & 0.821 & 0.785 & 0.558 \\
\hline CRS COMPROMISING & 0.633 & 0.855 & 0.601 & 0.408 \\
\hline
\end{tabular}




\begin{tabular}{lccll}
\hline CRS DOMINATING & 0.695 & 0.736 & 0.697 & 0.444 \\
EMOTIONAL INTELLIGENCE & 0.852 & 0.854 & 0.849 & 0.448 \\
OCB & 0.598 & 0.802 & 0.657 & 0.325 \\
WORKPLACE FRUSTRATION & 0.541 & 0.802 & 0.211 & 0.301 \\
\hline
\end{tabular}

The Cronbach alpha, composite reliability and average variance extracted (AVE) are given in Table 1. The obtained Cronbach's alpha values for CRS subscales: 0.692 (accommodating), 0.644 (avoiding) 0.778 (collaborating), 0.663 (compromising) and 0.695 (dominating). 0.541 Cronbach's alpha of workplace place frustration, 0.598 for OCB and 0.852 for emotional intelligence (EI). The Cronbach's alpha value ranges from 0.541 to 0.852 . The calculated value for composite reliability of CRS subscales were 0.691 (accommodating), 0.635 (avoiding), 0.785 (collaborating), 0.601(compromising) and 0.697 (dominating). The calculated reliability values of workplace frustration, OCB and emotional intelligence (EI) were $0.211,0.657$ and 0.849 respectively. Reliability ranging from 0.211 to 0.849 . Whereas, variance ranging from 0.301 to 0.558 . Cronbach's alpha is a convenient test used to estimate the reliability, or internal consistency, of a composite score. Cronbach's alpha is the measure of internal consistency, that is, how closely related a set of items are as a group. It is considered to be a measure of scale reliability; it expresses how reliable the measurement levels of the constructs are. Values that are closer to 1 are stronger and more reliable inconsistency.

\subsection{Discriminant Validity}

Discriminate validity can be defined as any single construct when differs from other constructs in the model (Carmines \& Zeller, 1979). Discriminate validity results are satisfactory when the constructs are having an AVE loading more than 0.5 which means that a minimum $50 \%$ of the variance was taken by the construct (Chin, 1998). Discriminate validity is established if the elements which are in diagonal are significantly higher than those values in off-diagonal in the parallel rows and columns. Discriminant Validity tests are being conducted to see whether non-related ideas or measurements are unrelated or not. An effective assessment of discriminant legitimacy demonstrates that a trial of an idea isn't exceptionally associated with different tests intended to quantify hypothetically various ideas. The table for Discriminant Validity is given below:

\begin{tabular}{|c|c|c|c|c|c|c|c|c|}
\hline & CRS_ACC & CRS_AVOI & CRS_COLL & CRS_COMP & CRS_DOM & EI & OCB & WF \\
\hline CRS_ACC & 0.657 & & & & & & & \\
\hline CRS_AVOI & 0.174 & 0.665 & & & & & & \\
\hline CRS_COLL & 0.615 & 0.013 & 0.747 & & & & & \\
\hline CRS_COMP & 0.530 & 0.447 & 0.301 & 0.639 & & & & \\
\hline CRS_DOM & -0.066 & 0.344 & -0.439 & 0.128 & 0.666 & & & \\
\hline EI & 0.527 & -0.037 & 0.511 & 0.409 & -0.221 & 0.669 & & \\
\hline
\end{tabular}




\begin{tabular}{lllllllll}
\hline OCB & 0.514 & -0.087 & 0.634 & 0.374 & -0.320 & 0.826 & 0.570 & \\
WF & 0.253 & -0.238 & 0.666 & 0.100 & -0.596 & 0.533 & 0.753 & 0.549 \\
\hline
\end{tabular}

\subsection{Model Fit Measures}

The fitness of the model in SEM-PLS is defined by various measures such as standardized root-mean-square residual (SRMR), and the exact model fits like d_ULS and d_G, Normed Fit Index (NFI), and $\chi^{2}$ (Chi-square). The model fit measures consisting of the measured value of both the saturated model, as well as the estimated model, are reported in the above Table. The saturated model assesses the correlation between all constructs. The estimated model, on the other hand, takes model structure into account and is based on the total effect scheme.

\begin{tabular}{lll} 
Fit Summary & Saturated Model & Estimated Model \\
\hline SRMR & 0.099 & 0.104 \\
d_ULS & 6.935 & 7.618 \\
d_G & 1.878 & 1.952 \\
Chi-Square & $2,625.938$ & $2,724.593$ \\
NFI & 0.524 & 0.506 \\
\hline
\end{tabular}

\subsection{Goodness of Fit for Outer Model}

For the inner model of Goodness, the fit test involves the evaluation in terms of R2 -value. The R2 can be identified from Smart PLS 3.2 and the results can be seen in the table below

\begin{tabular}{ccc}
\hline & R Square & R Square Adjusted \\
\hline ORGANISATIONAL CITIZENSHIP BEHAVIOUR & 0.773 & 0.764 \\
WORKPLACE FRUSTRATION & 0.766 & 0.757 \\
\hline
\end{tabular}

The variance of organizational citizenship behavior (OCB) is 0.773 and the variance of turnover is 0.766 , this condition has been fulfilled the $\mathrm{R} 2$ requirement which shows that the inner model is perfect and can be used to test the hypothesis.

\subsection{Hypothesis Testing}

In PLS-SEM, bootstrapping is one of the key strides, which gives the data of constancy of factor guesstimate. Sub-tests are drawn everywhere from the first example including substitution, in this process (Hair, Matthews, Matthews, \& Sarstedt, 2017). Bootstrapping provides information on the stability of the coefficient estimate. In this process, a large number of sub-samples are drawn from the original sample with replacement (Hair et al., 


\section{Macrothink Institute ${ }^{T M}$}

2016). After running the bootstrap routine, SmartPLS shows the $t$-values for structural model estimates derived from the bootstrapping procedure. The results of path coefficients for all the hypotheses are shown in the following table. The t-value greater than $1.96(\mathrm{p}<.005)$ shows that the relationship is significant at 95\% confidence level $(\alpha=0.05)$. Paths showing whether the relationship between measured and latent variables are significant or not. The path diagram showed in Figure 2.



Where

CRS ACCOMODATING * EMOTIONAL INTELLIGENCE <-

Moderating Effect 1

CRS ACCOMODATING * EMOTIONAL INTELLIGENCE <-

Moderating Effect 6

CRS AVOIDING * EMOTIONAL INTELLIGENCE <-

Moderating Effect 2

CRS AVOIDING * EMOTIONAL INTELLIGENCE <-

Moderating Effect 7

CRS COLLABRATING_ * EMOTIONAL INTELLIGENCE <-

Moderating Effect 3

CRS COLLABRATING_ * EMOTIONAL INTELLIGENCE <- 
Moderating Effect 8

CRS COMPROMISING * EMOTIONAL INTELLIGENCE <Moderating Effect 4

CRS COMPROMISING * EMOTIONAL INTELLIGENCE <Moderating Effect 9

CRS DOMINATING * EMOTIONAL INTELLIGENCE <Moderating Effect 5

CRS DOMINATING * EMOTIONAL INTELLIGENCE <Moderating Effect 10

$\begin{array}{lcr}\text { Original } & \text { T } \quad \text { Statistics } \\ \text { Sample } & (|\mathrm{O} / \mathrm{STDEV}|) & \\ \text { (O) } & & \end{array}$

\begin{tabular}{|c|c|c|c|}
\hline $\begin{array}{llll}\text { CRS ACCOMODATING } & -> & \text { ORGANISATIONAL } & \text { CITIZENSHIP } \\
\text { BEHAVIOUR } & & & \end{array}$ & 0.033 & 0.623 & 0.533 \\
\hline CRS ACCOMODATING -> WORKPLACE FRUSTRATION & -0.064 & 1.02 & 0.308 \\
\hline CRS AVOIDING -> ORGANISATIONAL CITIZENSHIP BEHAVIOUR & -0.084 & 0.884 & 0.377 \\
\hline CRS AVOIDING -> WORKPLACE FRUSTRATION & -0.122 & 0.915 & 0.361 \\
\hline $\begin{array}{l}\text { CRS COLLABRATING_ } \quad->\text { ORGANISATIONAL CITIZENSHIP } \\
\text { BEHAVIOUR }\end{array}$ & 0.236 & 3.777 & 0 \\
\hline CRS COLLABRATING_-> WORKPLACE FRUSTRATION & 0.365 & 6.6 & 0 \\
\hline $\begin{array}{l}\text { CRS COMPROMISING } \rightarrow \text { ORGANISATIONAL CITIZENSHIP } \\
\text { BEHAVIOUR }\end{array}$ & 0.098 & 1.964 & 0.05 \\
\hline CRS COMPROMISING -> WORKPLACE FRUSTRATION & -0.016 & 0.243 & 0.808 \\
\hline CRS DOMINATING -> ORGANISATIONAL CITIZENSHIP BEHAVIOUR & -0.059 & 1.106 & 0.269 \\
\hline CRS DOMINATING -> WORKPLACE FRUSTRATION & -0.279 & 2.129 & 0.033 \\
\hline $\begin{array}{l}\text { EMOTIONAL INTELLIGENCE }->\text { ORGANISATIONAL CITIZENSHIP } \\
\text { BEHAVIOUR }\end{array}$ & 0.531 & 11.646 & 0 \\
\hline EMOTIONAL INTELLIGENCE -> WORKPLACE FRUSTRATION & 0.248 & 4.444 & 0 \\
\hline ACCOMODATING * EI -> WORKPLACE FRUSTRATION & -0.2 & 3.159 & 0.002 \\
\hline DOMINATING*EI -> ORGANISATIONAL CITIZENSHIP BEHAVIOUR & 0.004 & 0.086 & 0.931 \\
\hline AVOIDING * EI -> WORKPLACE FRUSTRATION & 0.077 & 0.907 & 0.365 \\
\hline COLLABRATING*EI -> WORKPLACE FRUSTRATION & 0.153 & 2.818 & 0.005 \\
\hline COMPROMISING * EI -> WORKPLACE FRUSTRATION & -0.07 & 1.288 & 0.198 \\
\hline DOMINATING*EI -> WORKPLACE FRUSTRATION & -0.07 & 1.184 & 0.237 \\
\hline
\end{tabular}




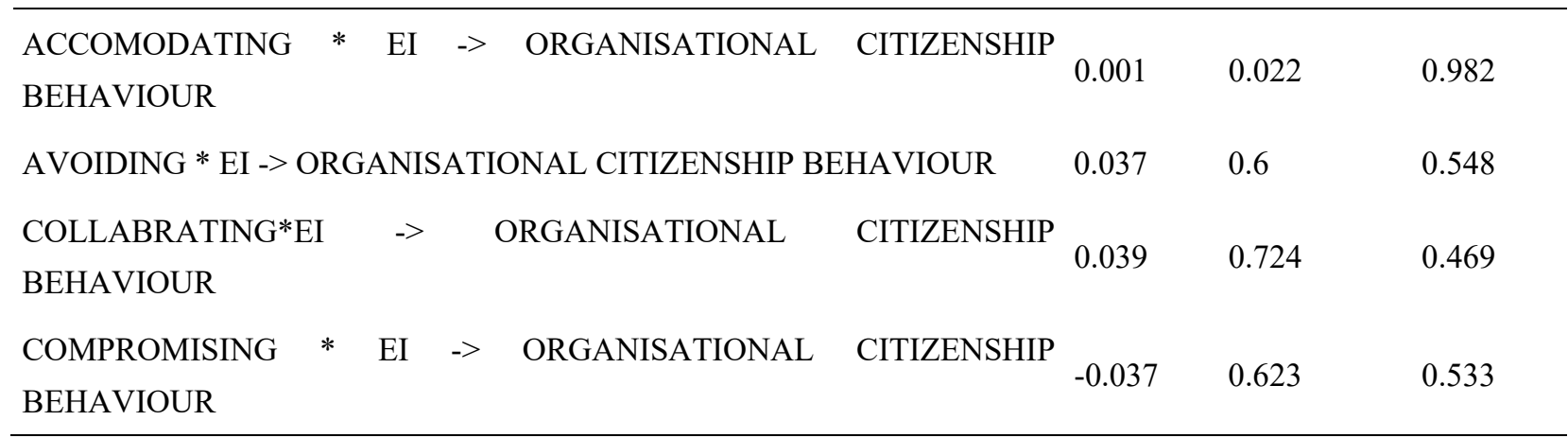

\subsection{Assessment of Hypothesize Model}

This research examined the relationship between the conflict resolution strategies with the workplace frustration and organizational citizenship behavior (OCB) and the moderating role of emotional intelligence (EI) on these relations. The research calculations conclude that; Hypothesis 1 which states that there is a significant relation between accommodating strategy and organizational citizenship behavior (OCB), has been rejected. Hypothesis 2 stating that there is a significant relationship between the accommodating strategy and workplace frustration that has been rejected as well. Hypothesis 3 and 4 were rejected stating there is a significant relationship between the avoiding strategy with workplace frustration and OCB. Hypothesis 5 has been accepted stating there is a significant relationship between collaborating strategy and OCB. Hypothesis 6 accepted, there is a significant relationship between collaborating strategy and workplace frustration. Hypothesis 7 is accepted as well as there is a significant relation between compromising strategy and OCB. Hypothesis 8 is rejected stating there is a significant relationship between compromising strategy and workplace frustration. Hypothesis 9 is rejected whereas, there is a significant relationship between dominating strategy and workforce frustration hypothesis 10 is accepted.

It is found that Emotional intelligence, as moderator has a significant effect on the relationship between accommodating strategy and workplace frustration and also on the relationship between collaborating strategy and workplace frustration. Rest of the hypothesis about the moderating role of emotional (EI) on the relationship between avoiding strategy and workplace frustration, compromising strategy and workplace frustration, dominating strategy and workplace frustration, accommodating strategy and $\mathrm{OCB}$, avoiding strategy and $\mathrm{OCB}$, collaborating strategy and $\mathrm{OCB}$, compromising strategy and $\mathrm{OCB}$, and dominating strategy and OCB are rejected. 

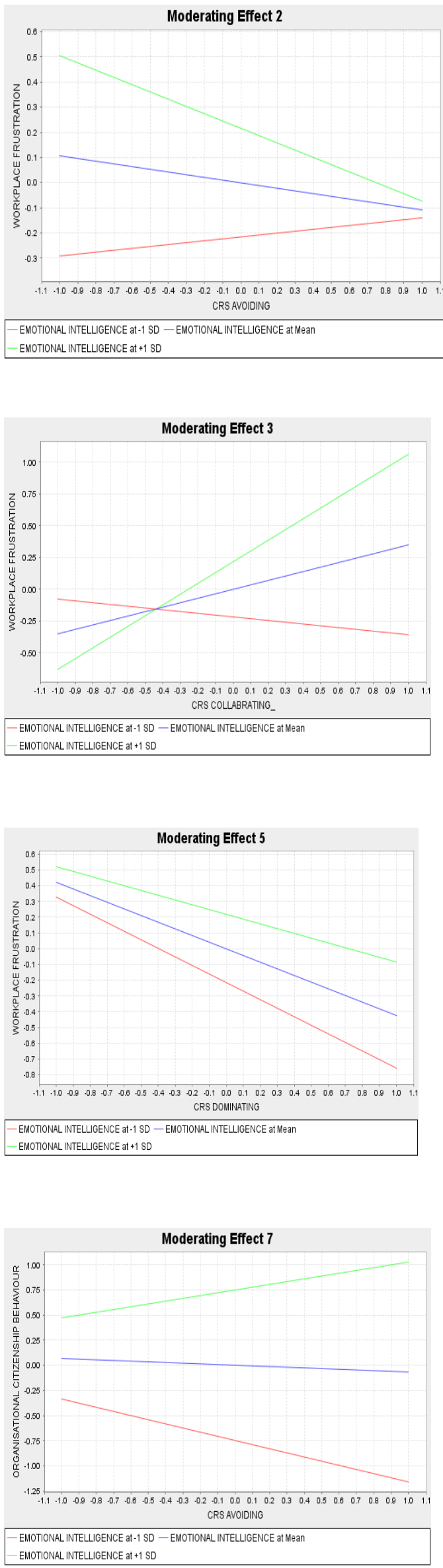


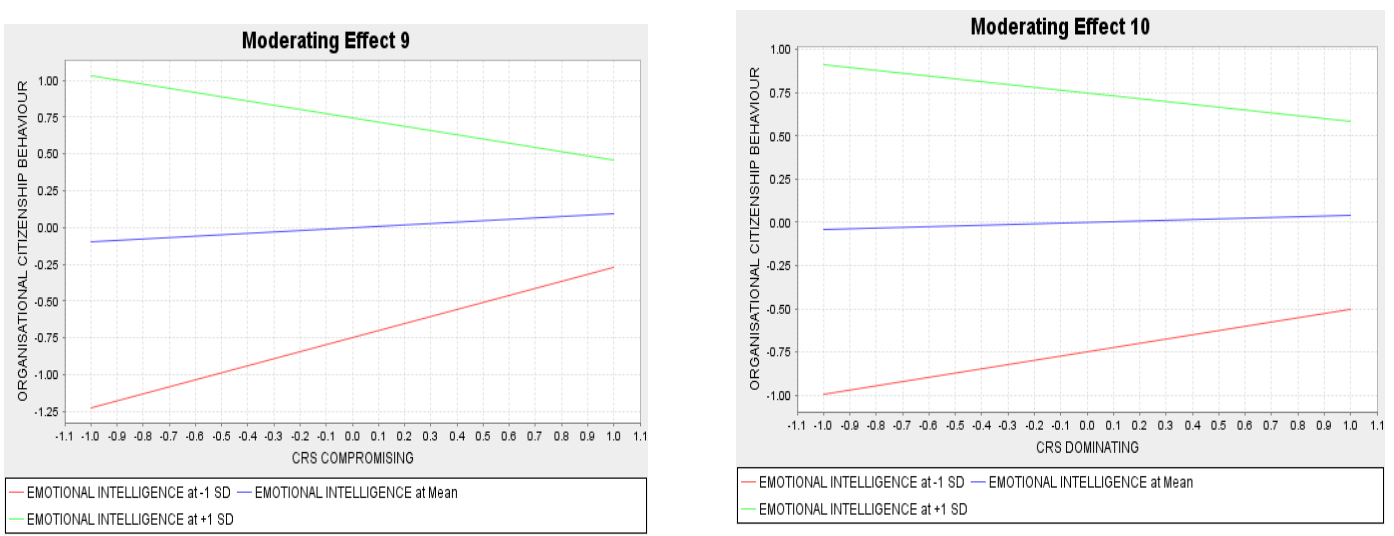

\section{Discussions}

The findings of the result indicate that accommodating, avoiding and compromising strategies are negatively associated with workplace frustration. Employees who are facing workplace frustration or those who are not satisfied with their workplace are not likely to deal with a conflict using these accommodating, avoiding and compromising ways of the strategies. Whereas these employees are likely to adopt the behavior associated dominating strategy, this finding of the study supports the findings of the study Alper et al.'s (2000), Meyer's (2004), and Wesolowski and Mossholder's (1997) findings. The reason behind this is because such employees/subordinates think they are not given the chance to share their opinion, feelings, and knowledge whenever a conflict arises so they feel like they are not part of this process of the resolution of conflict. When they think that they are not part of this process they feel frustrated. According to the findings such employees are expected to use collaborating behavior of the strategy to resolve the conflict as well as opposing the previous study Bolanle Ogungbamila (2006). Further, the findings of this study show that employees with discretionary behavior of OCB are positively associated with collaborating and compromising strategies of conflict resolution strategies. These findings are partially following the earlier researches (Alotaibi, 2001; Alper et al., 2000; Giap, Hackermeier, Jiao \& Wagdarikar, 2005; Meyer, 2004; Montoro-Rodriguez \& Small, 2006; Omoluabi, 2001). The only opposition with these studies is that the previous studies showed that the accommodating strategy positively supported the OCB as well but according to the findings of this study the accommodating strategy is negatively associated with OCB. The reason is that now the employees think that they must talk or confront the issue of conflict with their supervisors rather than sacrificing their goals and needs. The concern for the needs of oneself has grown over the years and contradicting previous studies. The further findings of the study show that avoiding and dominating strategies are negatively associated with OCB; the more the employees adopt these strategies the less they develop OCB. These findings of the study are in support of the previous studies results Alper et al. (2000), Meyer (2004), Alotaibi (2001) and Ogungbamila (2006). The reason behind this is because such employees/subordinates think they are not given the chance to share their opinion, feelings, and knowledge whenever a conflict arises so they feel like they are not part of this process of the resolution of conflict. When they start to think like in this manner then they are not likely 
to develop the organizational citizenship behavior as they feel like they are not owned bt their organization so they do not own it as well.

The findings also showed that the moderator emotional intelligence (EI) has a positive impact only on the relation between the accommodating strategy and workplace frustration, collaborating and workplace frustration. No significantly positive association as a moderator is found on the rest of the relations between the conflict resolution strategies and workplace frustration and OCB. Explanations of these findings show emotional intelligence (EI) can only be useful to moderate the intensity of the relations if the employees opt for an accommodating style of resolution while dealing with the workplace frustration, and collaborating style of resolution working with the supervisor while dealing with the workplace frustration. No impact of EI as a moderator is found on any relations between organizational citizenship behavior (OCB) and conflict resolution strategies to moderate $\mathrm{OCB}$ within employees.

\section{Conclusion}

This research examined the relationship between the conflict resolution strategies with the workplace frustration and organizational citizenship behavior (OCB) and the moderating role of emotional intelligence (EI) on these relations. To conduct the research, a questionnaire was developed which was solved by 298 respondents. The respondents were selected randomly working at the private organizations of the manufacturing and service industry. By this study, we conclude with the findings that conflict resolution strategies (accommodating, avoiding, compromising, collaborating, and competing) have a relation with the organizational citizenship behavior (OCB). Employees who prefer to use the collaborating strategy and compromising strategy to resolve the conflict are more likely to organizational citizenship behavior (OCB), accepting H5 and H7. They develop the feeling of owning their organization and they feel that their organization owns them as well. They think of themselves as being an important part of their organization. However, the results also show that the employees that use the collaborating strategy to resolve conflicts are more likely to develop the behavior of frustration regarding their workplace accepting the H6.

It was also found from the results that emotional intelligence as a moderator can moderate this relation between collaborating strategy and workplace frustration, accepting H13 and accepting H11 where emotional intelligence moderates the relation between the accommodating strategy and workplace frustrations. If employees manage and understand their emotions well, emotions related to the workplace and those around them can help them get over workplace frustration. There was no effect found of the moderator on the relations between the rest of the strategies and workplace frustration.

However no consistent effect of emotional intelligence was found on the relations between organizational citizenship behavior (OCB) with all the conflict resolution strategies (accommodating, avoiding, collaborating, compromising and dominating) as a moderator.

Previous studies have been conducting emphasizing the moderating role of emotional intelligence on conflict resolution strategies and Organizational citizenship behavior (OCB) but no previous study was conducted to know the role of emotional intelligence as a moderator on workplace frustration. 


\section{Macrothink}

An important theoretical implication of the findings from this study regarding the relationship between conflict resolution strategies and workplace frustration and in OCB is that organizations should have a psychologist at workplaces so that employees don't feel frustrated at their workplaces, can talk to the psychologist. In that way they can own their organization, their productivity will increase and they will voluntarily involve in doing the work which is not associated with their job (OCB). These organizational Psychologists should also include conflict resolution strategies and trait EI in a model design to enhance the OCB of workers in organizations.

\section{Limitations}

This study is not without its limitations, one of which is the self-report measures used in data collection. Future studies could, therefore, complement these measurements with other methods such as interviews and focus group discussion techniques. Another limitation was the unequal ratio of gender. Male respondents were huge in number as compared to the female respondents. The reason is less availability of females at workplaces/organizations than male employees. Lastly, this study used a heterogeneous group comprising employees of low, middle, and high ranks (with more in the lower ranks) working at the private organizations within the city of Karachi. This is a limitation. Future studies could involve employees either of low, middle, or high ranks to constitute a more homogeneous sample.

The study is subject to another limitation like having less knowledge on the subject of conflict management, although people working at the organizations deal with this issue several times but still having lesser knowledge of conflict management implications and how to use it efficiently.

\section{References}

Abraham, R. (1999). Trait EI in organisations: A conceptualization. Genetic, Social and General Psychology Monographs, 125(2), 209-224.

Albert, I. O. (2006). Conflict management and resolution in research supervision. Paper presented at the workshop on student supervision organized by The Postgraduate School, University of Ibadan Conference Centre, University of Ibadan. March 15-16, 2005.

Alotaibi, A. G. (2001). Antecedents of organisational citizenship behaviour: A study of public personnel in Kuwait. Public Personnel Management. https://doi.org/10.1177/ 009102600103000306

Alper, S., Law, K. S., \& Tjosvold, D. (2000). Conflict management efficacy, and performance on organisational teams.

Alper, S., Tjosvold, D., Law, K. (2012). Conflict Management, Efficacy, and Performance in Organizational Teams. Personnel Psychology, 53, 625-642. https://doi.org/10.1111/j.1744 $-6570.2000 . t b 00216 . x$

Amason, A. (1996). Distinguishing the Effects of Functional and Dysfunctional Conflict on Strategic Decision Making: Resolving a Paradox for Top Management Teams. The Academy of Management Journal, 39(1), 123-148. https://doi.org/10.5465/256633 


\section{Macrothink}

Human Resource Research

ISSN 1948-5441 2020, Vol. 4, No. 1

Baron, R., \& Kenny, D. (1987). The Moderator-Mediator Variable Distinction in Social Psychological Research. Journal of personality and social psychology, 51, 1173-82. https://doi.org/10.1037/0022-3514.51.6.1173

Berkowitz, L. (1989). Frustration-aggression hypothesis: Examination and reformation. Psychological Bulletin, 106, 59-73. https://doi.org/10.1037/0033-2909.106.1.59

Bogg, J., \& Cooper, C. L. (1994). An examination of gender difference for job satisfaction, metal health, and occupational stress among senior U.K civil servants. International Journal of Stress Management. https://doi.org/10.1007/BF01857609

Canaan, M. L., Karkoulian, S., \& El-Kassar, Abdul-Nasser. (2016). Conflict resolution styles and personality: The moderating effect of generation $\mathrm{X}$ and $\mathrm{Y}$ in a non-Western context. International Journal of Productivity and Performance Management, 65, 792-810. https://doi.org/10.1108/IJPPM-01-2016-0014

Carmeli, A. (2003). The relationship between trait EI and work attitudes, behaviour and outcomes. Journal of Managerial Psychology, 18(8), 788-813. https://doi.org/10.1108/ 02683940310511881

Carmines, E. G., \& Zeller, R. A. (1979). Reliability and Validity Assessment (Vol. 17). Thousand Oaks, CA: Sage. https://doi.org/10.4135/9781412985642

Chen, M., \& Ayoko, O. (2012). Conflict and trust: The mediating effects of emotional arousal and self-conscious emotions. International Journal of Conflict Management, 23, 19-56. https://doi.org/10.1108/10444061211199313

Chin, W., \& Marcoulides, G. (1998). The Partial Least Squares Approach to Structural Equation Modeling. Modern Methods for Business Research, 8.

Decktop, J. R., Mangel, R., \& Cirka, C. C. (1999). Getting more than you pay for: Organisational Citizenship Behaviour and pay-for-performance plans. Academy of Management Journal, 42, 420-428. https://doi.org/10.5465/257012

Deutsch, M. (1990). Sixty years of conflict. The International Journal of Conflict Management, 1, 237-263. https://doi.org/10.1108/eb022682

Dzurgba, A. (2006). Prevention and management of conflict. Ibadan: Loud Books (Publishers).

Foran, V. (2001). Employees concerned about workplace violence. Occupational Hazards, 63(9), 27.

Fox, S., Spector, P. E., \& Miles, D. (2001). Counterproductive work behavior (CWB) in response to job stressors and organizational justice: Some mediator and moderator tests for autonomy and emotions. Journal of Vocational Behavior, 59, 291-309. https://doi.org/10. 1006/jvbe.2001.1803 


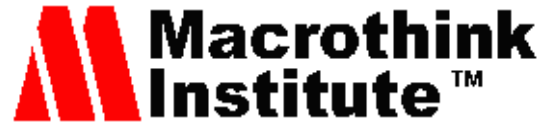

Friedman, R., Tidd, S., Currall, S., \& Tsai, J. (2000). What Goes Around Comes Around: The Impact of Personal Conflict Style on Work Conflict and Stress. International Journal of Conflict Management, 11, 32-55. https://doi.org/10.1108/eb022834

Furnham, A., \& Petrides, K. (2003). Trait emotional intelligence and happiness. Social Behaviour and Personality, 31(8), 815-824. https://doi.org/10.2224/sbp.2003.31.8.815

Geher, G., Warner, R. M., \& Brown, A. S. (2001). Predictive validity of the emotional accuracy research scale. Intelligence, 29(5), 373-388. https://doi.org/10.1016/S01602896(00)00045-3

Gelfand, M., Nishii, L., Holcombe, K., Dyer, N., Ohbuchi, K., \& Fukuno, M. (2002). Cultural influences on cognitive representations of conflict: Interpretations of conflict episodes in the United States and Japan. The Journal of applied psychology, 86, 1059-74. https://doi.org/10.1037/0021-9010.86.6.1059

Goh, A., Bruursema, K., Fox, S., \& Spector, P. E. (2003, April). Comparisons of self and co-workers reports of counterproductive work behavior. Presented at the poster session of the meeting of the Society for Industrial and Organizational Psychology, Orlando, Florida. https://doi.org/10.1037/e518712013-323

Graziano, W. G., \& Eisenberg, N. (1997). Agreeableness: A dimension of personality. In R. Hogan, J. A. Johnson, \& S. R. Briggs (Eds.), Handbook of personality psychology (pp. 795-824). Academic Press. https://doi.org/10.1016/B978-012134645-4/50031-7

Graziano, W., Jensen-Campbell, L., \& Hair, E. (1996). Perceiving Interpersonal Conflict and Reacting to It: The Case for Agreeableness. Journal of personality and social psychology, 70, 820-35. https://doi.org/10.1037/0022-3514.70.4.820

Gredler, G. R., Alexander, K. L., Entwisle, D. R., \& Dauber, S. L. (1995). On the success of failure: A reassessment of the effects of retention in the primary grades. New York: Cambridge University Press.

Hackman, J. R., \& Morris, C. G. (1975). Group tasks, group interaction process, and group performance effectiveness: A review and proposed integration. Berkowitz L Advances in experimental social psychology (Vol. 8). New York: Academic Press. https://doi.org/10. 1016/S0065-2601(08)60248-8

Hair, J., Black, W., Babin, B., \& Anderson, R. (2009). Multivariate data analysis. Prentice Hall. London.

Hayes, A. F. (2013). Methodology in the social sciences. Introduction to mediation, moderation, and conditional process analysis: A regression-based approach. Guilford Press.

Hoffman, B. J, Blair, C. A., Meriac, J. P., \& Woehr, D. J. (2007). Expanding the criterion domain? A quantitative review of the OCB literature. Journal of Applied Psychology, 92(2), 555-566. https://doi.org/10.1037/0021-9010.92.2.555 


\section{Macrothink}

Human Resource Research

ISSN 1948-5441 2020, Vol. 4, No. 1

Hopkins, M., \& Yonker, R. (2015). Managing conflict with emotional intelligence: abilities that make a difference. Journal of Management Development, 34(2), 226-244. https://doi.org/10.1108/JMD-04-2013-0051

Howart, G., \& London, M. (1980). Attributions of conflict management strategies in superior subordinate dyads. Journal of Applied Psychology, 65, 172-175. https://doi.org/10.1037/0021 $-9010.65 .2 .172$

Johnson, P., \& Indvik, J. (2001). Slings and arrows of rudeness: Incivility in the workplace. Journal of Management Development, 20, 705-714. https://doi.org/10.1108/EUM00000 00005829

Jr, J., Matthews, L., Matthews, R., \& Sarstedt, M. (2017). PLS-SEM or CB-SEM: updated guidelines on which method to use. International Journal of Multivariate Data Analysis, 1. https://doi.org/10.1504/IJMDA.2017.087624

Kolb, J. (2013). Conflict management principles for groups and teams. Industrial and Commercial Training, 45. https://doi.org/10.1108/00197851311309516

LePine, J. A., Erez, A., \& Johnson, D. E. (2002). The nature and dimensionality of organisational citizenship behaviour: A critical review and meta-analysis. Journal of Applied Psychology, 87, 52-65. https://doi.org/10.1037/0021-9010.87.1.52

Martinko, M. J., Gundlach, M. J., \& Douglas, S. C. (2002). Counterproductive behavior: A causal reasoning perspective. Interpersonal Journal of Selection and Assessment, 10, 36-50. https://doi.org/10.1111/1468-2389.00192

Mayer, J. P., \& Salovey, P. (1997). What is trait EI? Implications for educators. In P. Salovey, \& D. Sluyter (Eds.), Emotional Development, Emotional Literacy, and Trait EI: Educational Implications (pp. 31-34). New York: Basic Books.

McShane, S. L., \& von Glinow, M. A. (2000). Organizational Behavior. McGraw-Hill, Boston.

Meyer, D. (2004). Protest and Political Opportunities. Annual Review of Sociology, 30, 125-145. https://doi.org/10.1146/annurev.soc.30.012703.110545

Meyer, S. (2004). Organizational response to conflict: Future conflict and work outcomes. Social Work Research, 28, 183-190. https://doi.org/10.1093/swr/28.3.183

Mikolajczak, M., Petrides, K., Coumans, N., \& Luminet, O. (2009). The moderating effect of trait emotional intelligence on mood deterioration following laboratory-induced stress. International journal of clinical and health psychology, 9(3).

Montoro, R. J., \& Small, J. (2006). The Role of Conflict Resolution Styles on Nursing Staff Morale, Burnout, and Job Satisfaction in Long-Term Care. Journal of aging and health, 18, 385-406. https://doi.org/10.1177/0898264306286196 


\section{Macrothink Institute ${ }^{T M}$}

Montoya-Weiss, M. M., Massey, A. P., \& Song, M. (2001). Getting it together: Temporal coordination and conflict management in global virtual teams. Academy of Management Journal, 44(6), 1251-1262. https://doi.org/10.2307/3069399

Mullins, L. J. (1996). Management and organizational behaviour (4th ed, p. 483). London: Pitman Publishing.

Ogungbamila, B. (2006). Relational conflict resolution strategies (RCRS) and workplace frustration. Journal of Psychology in Africa, 16(1), 59-64. https://doi.org/10.1080/14330237. 2006.10820105

Ogungbamila, B. (2012). Occupational Burnout Among Employees in Some Service Occupations in Nigeria: Are Health Workers Different? Psychological Thought, 6(1), 153-165.

Omoluabi, P. F. (2001). Principles and Processes of Conflictology. IFE PsychologIA. https://doi.org/10.4314/ifep.v9i3.23627

Omoluabi, P. F. (2001). Principles of processes of conflictology. Ife Psychologia, 9(3), 1-13. Organ, D. W. (1988). Organisational citizenship behaviour: The good soldier syndrome, Lexington, MA: Lexington Books. https://doi.org/10.4314/ifep.v9i3.23627

Ongori, H. (2009). Organisational Conflict and its Effects on Organisational Performance. Research Journal of Business Management, 3, 16-24. https://doi.org/10.3923/rjbm. 2009.16.24

Organ, D. W. (1988). Organizational Citizenship Behavior: The Good Soldier Syndrome. Lexington Books/D. C. Heath and Com, Lexington, MA.

Organ, D. W. (1988). Organisational citizenship behaviour: The good soldier syndrome. Lexington, MA: Lexington Books.

Oucho, J. O. (2002). Refugees and Internally Displaced Persons: Africa's Liability for the Next Millennium. In D. Joly (Ed.), Global Changes in Asylum Regimes. Migration, Minorities and Citizenship. Palgrave Macmillan, London. https://doi.org/10.1057/9781 403914149_9

Pearson, C., Andersson, L., \& Porath, C. (2000). Assessing an attacking workplace incivility. Organizational Dynamics, 29, 123-137. https://doi.org/10.1016/S0090-2616(00)00019-X

Perry, P. M. (2000). Zero tolerance. I ndustrial Distribution, 89(5), 56-60.

Petrides, K. V., \& Furnham, A. (2003). Trait emotional intelligence: Behavioral validation in two studies of emotion recognition and reactivity to mood induction. European Journal of Personality, 17, 39-57. https://doi.org/10.1002/per.466

Pinkley, R. (1990). Dimensions of Conflict Frame: Disputant Interpretations of Conflict, 75, 117-126. https://doi.org/10.1037/0021-9010.75.2.117 
Podsakoff, N., Whiting, S., Podsakoff, P., \& Blume, B. (2009). Individual- and Organizational-Level Consequences of Organizational Citizenship Behaviors: A Meta-Analysis. Journal of Applied Psychology, 94. https://doi.org/10.1037/a0013079

Podsakoff, P. M., Ahearne, M., \& MacKenzie, S. B. (1997). Organizational citizenship behavior and the quantity and quality of work group performance. Journal of Applied Psychology, 82, 262-270. https://doi.org/10.1037/0021-9010.82.2.262

Rahim, A., \& Bonoma, T. V. (1979). Managing Organizational Conflict: A Model for Diagnosis and Intervention. Psychological Reports, 44(3_suppl), 1323-13. https://doi.org/10. 2466/pr0.1979.44.3c.1323

Rahim, A. M. (2002). Toward a Theory of Managing Organizational Conflict. The International Journal of Conflict Management, 13(3), 206-23. https://doi.org/10.1108/ eb022874

Rahim, M. A. (1983). A measure of styles of handling interpersonal conflict. Academy of Management Journal, 26(2), 368-376. https://doi.org/10.5465/255985

Reich, W., Wagner-Westbrook, B., \& Kressel, K. (2007). Actual and Ideal Conflict Styles and Job Distress in a Health Care Organization. The Journal of psychology, 141, 5-15. https://doi.org/10.3200/JRLP.141.1.5-15

Runde, C., \& Flanagan, T. (2008). Conflict competent leadership. Leader To Leader, 46-51. https://doi.org/10.1002/lt1.268

Salami, S. O. (2010). Conflict resolution strategies and organizational citizenship behavior: The moderating role of trait emotional intelligence. Social Behavior and Personality: An international journal, 38, 75-86. https://doi.org/10.2224/sbp.2010.38.1.75

Shrout, P. E., \& Bolger, N. (2002). Mediation in experimental and nonexperimental studies: New procedures and recommendations. Psychological Methods, 7(4), 422-445. https://doi.org/10.1037/1082-989X.7.4.422

Spector Paul, E. (1994). Job Satisfaction Survey. Tampa, FL: Department of Psychology, University of South Florida.

Spector, P. E. (1975). Relationships of organizational frustration with reported behavioral reactions of employees. Journal of Applied Psychology, 60, 635-637. https://doi.org/10.1037/ h0077157

Thomas, K. (1992). Conflict and Conflict Management: Reflections and Update. Journal of Organizational Behavior, 13(3), 265-274. https://doi.org/10.1002/job.4030130307

Ting-Toomey, S. (2012). Understanding Intercultural Conflict Competence: Multiple Theoretical Insights.

Tjosvold, D., Law, K. S., \& Sun, H. (2006). Effectiveness of Chinese Teams: The Role of Conflict Types and Conflict Management Approaches. Management and Organization Review, 2, 231-252. https://doi.org/10.1111/j.1740-8784.2006.00040.x 


\section{Macrothink}

Human Resource Research

ISSN 1948-5441 2020, Vol. 4, No. 1

Trapnell, P. D., \& Wiggins, J. S. (1990). Extension of the Interpersonal Adjective Scales to Include the Big Five Dimensions of Personality. Journal of Personality and Social Psychology, 59, 781-790. https://doi.org/10.1037/0022-3514.59.4.781

Uline, C., Tschannen-Moran, M., \& Perez, L. (2003). Constructive Conflict: How Controversy Can Contribute to School Improvement. Teachers College Record - TEACH COLL REC, 105, 782-815. https://doi.org/10.1111/1467-9620.00268

Van der Geer, J., Hanraads, J. A. J., \& Lupton R. A. (2000). The art of writing a scientific article. Journal of Scientific Communications, 163, 51-59.

Wesolowski, M. A., \& Mossholder, K. W. (1997). Relational demography in supervisor-subordinate dyads: Impact on subordinate job satisfaction, burnout, and perceived procedural justice. Journal of Organizational Behavior, 18(4), 351-362. https://doi.org/10. 1002/(SICI)1099-1379(199707)18:4\%3C351::AID-JOB802\%3E3.0.CO;2-\#

Williams, L. J., \& Anderson, S. E. (1991). Job satisfactory and organisational commitment as predictors of organisational citizenship and in-role behaviours. Journal of Management, 17, 601-617. https://doi.org/10.1177/014920639101700305

Yuan, W. (2010). Conflict management among American and Chinese employees in multinational organizations in China. Cross Cultural Management: An International Journal. https://doi.org/10.1108/13527601011068388

Zhang, S. J., Chen, Y., \& Sun, H. (2015). Emotional intelligence, conflict management styles, and innovation performance: An empirical study of Chinese employees. International Journal of Conflict Management, 26. https://doi.org/10.1108/IJCMA-06-2014-0039

\section{Glossary}

AAB Device: an equipment for sky.

KKD Device: an equipment for shipping.

\section{Appendix}

Appendix 1. Survey Question for Mobilephone Marketing

Appendix 2. Model of Population

\section{Copyright Disclaimer}

Copyright for this article is retained by the author(s), with first publication rights granted to the journal.

This is an open-access article distributed under the terms and conditions of the Creative Commons Attribution license (http://creativecommons.org/licenses/by/4.0/). 